\title{
¿Es posible una estética del crimen?
}

\author{
¿Is possible the aesthetics of crime?
}

\author{
Juan Ramón RODRÍGUEZ LLAMOSÍ \\ Magistrado. Decano de los Juzgados de Alcorcón \\ Doctor en Ciencias jurídicas. Máster en Humanidades
}

\begin{abstract}
Resumen: El presente trabajo trata de dar respuesta a una cuestión, escasamente tratada y estudiada por los juristas, que relaciona dos conceptos dispares entre sí como son la estética, procedente de la Filosofia, y el crimen, procedente del Derecho. Partiendo de la pregunta que encabeza el ensayo acerca de si es posible una estética del crimen aborda las dos caras de la cuestión: el aspecto moral del crimen, esto es, la cuestión ética, en la medida en que el crimen es un acto que se aparta del bien; y el aspecto estético, es decir, la espectacularización del horror mediante su escenificación y presentación en los medios de comunicación, así como en el arte y, en particular, en la pintura, la fotografía y la literatura, en los que ponemos como referencia ejemplos particulares.
\end{abstract}

Abstract: The present work studies the relationship between aesthetics and crime. The essay examines two aspects of the problem: the aspect moral of crime, because all crime departs from the good; and the aspect aesthetic of crime, the spectacle of horror, its staging in the media and in art, particularly in painting, photography and literature, with particular examples.

Palabras clave: Estética, injusticia, horror, crimen, espectáculo, escena

Keywords: Aesthetic, injustice, horror, crime, spectacle, scene

\section{Sumario:}

I. Presentación.

II. La cuestión moral del crimen.

III. La cuestión estética del crimen.

Recibido: agosto 2020.

Aceptado: octubre 2020. 



\section{PRESENTACIÓN}

En el año 1827, Thomas de Quincey (1785-1859) publicó un exquisito libro y único en su género titulado Del asesinato considerado como una de las Bellas Artes en el que reivindica una visión estética del asesinato al abordar la posibilidad de contemplar éste desde una perspectiva artística ${ }^{1}$.

No exento de una macabra ironía, como lo fue el escrito años atrás en 1729 por Jonathan Swift titulado Una modesta proposición, y del que parece haber tomado el mismo fino sarcasmo ${ }^{2}$, el libro hace un recorrido por el arte del asesinato desde la más remota antigüedad pasando por Caín, a quien califica de hombre de genio extraordinario, y hasta el mismo Viejo de la Montaña, fundador de la Secta de los Asesinos, y repara en las atrocidades de sus contemporáneos como Descartes, que estuvo a punto de morir a manos de unos desalmados; Spinoza, asesinado por un médico; Malebranche, también asesinado; o Kant, librado de la muerte por un escrúpulo del asesino.

De la misma manera que hay filósofos, es decir, amantes de la sabiduría, el libro sostiene que hay personas, apartadas de la moral, amantes del asesinato y que suelen reunirse cada vez que se comete alguno para hacer su crítica como si de un cuadro, de una escultura o de otra obra de arte se tratara, y observar

${ }^{1}$ DE QUINCEY, T., Del asesinato considerado como una de las Bellas Artes, Madrid 1995. El libro fue originalmente publicado en la revista Blackwood en dos partes, en 1827 y en 1839, con un extenso Post Scriptum de 1854. Y aparece concebido de manera irónica, como el que años antes había publicado Swift titulado Una modesta proposición destinada a evitar que los niños de Irlanda sean una carga para sus padres y el país, en el que proponía una solución radical al exceso de niños irlandeses: cocinarlos y comérselos.

${ }^{2}$ El libro recuerda la ironía del ensayo escrito por Jonathan Swift en 1729 titulado Una modesta proposición en el que propone resolver el problema en Irlanda de campesinos inquilinos que no pueden alimentar a sus hijos porque los propietarios son inflexibles sobre el arriendo. Después de discutir el problema, sugiere una solución nueva: los padres deben vender sus hijos a los terratenientes ricos para que se los coman. El objetivo del autor es enfrentar a la sociedad irlandesa con las condiciones deplorables de los jornaleros y campesinos de su país. Sus vehículos de transmisión eran el sarcasmo, la ironía y el humor negro. La obra se ha convertido en un referente indiscutible del género ensayístico. Puede leerse en https://www.biblioteca.org.ar/ libros/158423.pdf. 
el crimen, lo morboso, lo injusto como una posibilidad creadora. Y propone para el enjuiciamiento estético correcto de un crimen una serie de principios: que la víctima sea una buena persona, no sea demasiado famosa, goce de buena salud y tenga hijos pequeños que dependan de él. La finalidad última del asesinato es la misma que Aristóteles asigna a la tragedia griega tan llena precisamente de asesinatos $^{3}$ : purificar el corazón mediante la compasión y el temor. A titulo ejemplar, el libro termina con la descripción metódica de los asesinatos cometidos por un tal John Williams en 1812 quien exterminó a dos familias enteras y por los hermanos M'Kean en las proximidades de Manchester cuando eliminaron a varios miembros de una familia y fueron ejecutados en Lancaster ${ }^{4}$.

Algo parecido a Thomas de Quincey hizo el escritor hispano-franco-mexicano Max Aub (1903-1972) quien publicó en el año 1957 un curioso librito titulado Crímenes ejemplares en el que recoge una recopilación que había ido haciendo a lo largo de su vida con las explicaciones dadas acerca de sus crímenes por una serie de asesinos tanto de Francia como de España y de México ${ }^{5}$. En él, el escritor no rehúye ni oculta el aspecto ético ni estético del hecho, si se tiene en cuenta que se presentan como ejemplares una serie de crímenes cuya definición implica ser dignos de ser propuestos como modelo, al modo como lo serían las famosas Novelas ejemplares de Cervantes, lo cual resulta paradójico pues estos criminales no constituirían precisamente un modelo de buena conducta, por más que alguno de estos cínicos criminales considere que su acción ha sido ejemplar al cumplir un servicio a la sociedad.

El carácter paradójico de estos crímenes ejemplares es que en ellos se invierten los papeles de víctima y verdugo: los asesinos reivindican las razones de su violencia y se presentan como justicieros, buscando la complicidad del lector, en este caso juez de la causa que postulan. Es más, es que el criminal se presenta como una víctima que actúa en su propia defensa ejecutando un castigo ejemplar. Es la más pura ruptura del sistema de valores morales y éticos.

Tras presentar su obra, el escritor expresa una profunda reflexión sobre la insensatez del hombre contemporáneo, su mediocridad y falta de ideales, borrando los confines entre hombre normal y asesino:

\footnotetext{
${ }^{3}$ Recuérdese que Orestes mató a su madre, Edipo a su padre, Medea a todos sus hijos...

${ }^{4}$ En estas dos crónicas encontramos la fuente de dos historias: el cuento Los señores Burke y Hare, Asesinos, de Marcel Schwob, que puede leerse en: https://ciudadseva.com/texto/los-senoresburke-y-hare-asesinos/ y la conocida Historia Universal de la Infamia, de Jorge Luis Borges, que puede leerse en http://biblio3.url.edu.gt/Libros/borges/infamia.pdf.

${ }^{5}$ El autor comenzó a recopilar sus crímenes entre 1949 y 1950, pero la obra no fue publicada en España hasta el año 1972, año de la muerte de Max Aub, en la editorial Lumen y precisamente en una colección denominada Palabra Menor. Antes de esa fecha sólo se había publicado alguna antología breve de crímenes, de suicidios, de epitafios y de gastronomía.
} 
El hombre de nuestro tiempo solo considera fracasos. El último gran mito cae ya, no de viejo, sino por potente. La grandeza humana solo se mide por lo que pudo ser. No vamos a ninguna parte, el gran ideal es, ahora, la mediocridad; vencer los impulsos [...] En su submundo estos humildes criminales se explican aquí sin saber siquiera cómo; pero no creo que den lástima. En eso son tan mediocres como nosotros, que no nos atrevemos a gritar en el enorme proceso de nuestro tiempo. Aceptamos lo que nos imponen con voluntad deliberada, no discrepamos, todos conformes [...] Nunca estuvimos más cerca de la tierra. Nos tragará sin rastro. No le echemos a nadie la culpa, se perdió la siembra, tal vez por el mal tiempo ${ }^{6}$.

La ironía del texto y una fuerte carga sensorial encierra, a mi juicio, un mensaje moral. Es un grito de dolor contra la intolerancia humana que invade el mundo gobernado por la maldad, en el que los hombres llegan a cometer un crimen por motivos ridículos y triviales. Esta consideración se ve reforzada por el pensamiento de Max Aub, quien en su diario privado escribía, en 1963, un axioma tan veraz como cruel:

El hombre es el único animal capaz de hallar razones para matar a sus semejantes, y hacerlo?.

Cuando Thomas de Quincey o cuando Max Aub nos relatan la obra de asesinos no se refieren al criminal que comete el hecho y huye, sino que se fijan en el cuadro que éste deja atrás. Su interés está en la apreciación de la muerte en sus aspectos escénicos o valores comparativos, no en criticar el horror. Es la visión del crimen en su impacto escénico donde se califica la maldad por la crueldad de sus valores plásticos. El crimen es reprobable siempre pero parecen destacar que, una vez consumado, algo ha de obtenerse de él: los detalles sangrientos quedan para el pueblo, pero el hombre refinado debe buscar el detalle elegante que convierta al asesinato en una verdadera obra de arte. De esta manera, se anuncia la estética del crimen, de lo injusto, de lo que se aparta de la ley y la moral. Se pregunta de Quincey:

Cuando la víctima ha dejado de sufrir ¿de qué sirve aún más virtud? Ya hemos dado lo suficiente a la moralidad: ha llegado la hora del buen gusto y de las Bellas Artes.

\footnotetext{
${ }^{6}$ AUB, M., Crimenes Ejemplares, Madrid, 2011, p. 14-15.

${ }^{7}$ AUB, M., Diarios inéditos, Sevilla, 1963, p. 259.

${ }^{8}$ DE QUINCEY, T., Del asesinato considerado como una de las Bellas Artes, Madrid 1995.
} 
Kant consideraba como bellas artes la poesía, la música, la pintura y el dibujo, aunque las bellas artes eran seis: arquitectura, escultura, pintura, música, declamación y danza. La declamación incluye la poesía, y la música el teatro. Y a ellas se une hoy en día el cine, considerado por esto el séptimo arte. Pues bien, cuando de Quincey añade el asesinato como una de las bellas artes que se ha ido perfeccionando desde Caín está pensando en las ideas de Kant acerca de que el arte es un fin en si mismo y de que, en la medida en que el asesino se convierte en un semidiós o un pequeño dios que decide el destino de otro ser mediante un acto firme, y no como medio de venganza o de obtener dinero, está creando y esta creación es arte con independencia de que, moral y jurídicamente, el hecho injusto sea reprobable?

Uno termina la lectura de libros como estos preguntándose: ¿puede obtenerse realmente algo bello de un asesinato?, ¿se puede contemplar el asesinato como una obra de arte?, ¿qué hay de elegante en lo sangriento, en la crueldad, en la maldad, en el sufrimiento ajeno, en la sinrazón de quitar la vida a un semejante?, ¿se puede analizar el diseño, la disposición del cuerpo, la luz y la sombra como factores indispensables para juzgar el valor estético de un asesinato?, ¿realmente puede ser bello un crimen?, ¿se puede apreciar belleza en algo injusto?, ¿podemos sostener una estética del crimen?, ¿es posible concebir la destrucción de un semejante como un acto de emoción creadora?, ¿se puede desnudar de moralidad un crimen y aprehender únicamente su efecto estético?, ¿es posible disfrutar de manera estética de la muerte cruel y violenta?, ¿cómo podemos admirar estéticamente algo que condenamos moral y jurídicamente?. En definitiva, y éste es el objeto de este ensayo, ¿es posible una estética del crimen?

Para responder a estas cuestiones hay que abordar sus dos aspectos: el primero, es el aspecto moral, es decir, si un hecho aunque sea injusto e inmoral puede ser realmente bello, de la misma manera que en el arte hay un espacio para la apreciación de la estética de lo feo; $\mathrm{y}$, el segundo aspecto, es la estética del crimen propiamente, desde su aspecto plástico, mediante su escenificación y espectacularización, esto es, su presentación en los medios de comunicación, y en la fotografía, la pintura y la literatura.

\footnotetext{
${ }^{9}$ Kant en su obra Crítica del juicio establecía tres definiciones de la belleza: La primera es la que explica qué es arte: Cuando el arte, adecuado al conocimiento de un objeto posible, ejecuta los actos que se exigen para hacerlo real, es mecánico, pero si tiene como intención inmediata el sentimiento del placer, llámase arte estético. Este es: o arte agradable, o bello por bellas artes. La segunda dice: Arte bello... es un modo de representación que por si mismo es conforme a fin, $y$, aunque sin fin, fomenta, sin embargo, la cultura de las facultades del espiritu para la comunicación social. La tercera sostiene que El arte bello muestra precisamente su excelencia en que describe como bellas, cosas que en la naturaleza serían feas o desagradables.
} 
Thomas de Quincey decía:

Todo en este mundo tiene dos caras. El asesinato, por ejemplo, puede ser tomado por su cara moral... y eso, lo confieso, es su lado más débil; o puede también ser tratado estéticamente, como dicen los alemanes, es decir, en relación con el buen gusto ${ }^{10}$.

Pues vamos a comenzar, primero, por el aspecto moral del crimen.

\section{LA CUESTIÓN MORAL DEL CRIMEN}

La teoría de las bellas artes, las normas del buen gusto, la ciencia de la estética ha elaborado ampliamente concepciones y estudios sobre lo bello y lo sublime e incluso sobre lo feo ${ }^{11}$, pero poco o nada se ha dicho o se ha escrito sobre la estética del crimen, a pesar de que Thomas de Quincey reivindicó la posibilidad de contemplar el crimen desde una perspectiva artística al admitir una visión estética del asesinato, y a pesar también de que vivimos inmersos en sociedades en las que estamos rodeados de injusticias humanas que presenciamos o nos son servidas en bandeja a través de los medios de comunicación.

Ciertamente, en la estética la otra cara de la moneda de lo bello es lo feo; en la ética el mal es el reverso del bien; y en la justicia lo injusto es el negativo de lo justo. Sin embargo, difícilmente nos paramos a pensar si existe belleza en el lado negativo de cada una de estas categorías positivas: ni en lo feo, ni en lo malo y, mucho menos, en lo injusto, a pesar de que, cuando se producen hechos criminales, muchas personas degustan con interés morboso estos hechos injustos y execrables.

A la filosofía alemana le corresponde el honor de haber tenido el valor de haber reconocido lo feo como lo negativo de la idea estética, como un momento integrante de ella y también haber reconocido que de lo bello se pasa a lo cómico a través de lo feo. Sin embargo, el tratamiento del concepto de lo injusto desde la perspectiva estética ha escapado a cualquier reflexión filosófica y es hasta ahora inexistente.

Desde luego, hablar de una estética de lo injusto puede que resulte extraño, pero ¿por qué no?, ¿por qué no podemos juzgar estéticamente un hecho injusto que afecta a nuestra sensibilidad más allá de lo moral y lo jurídico?, ¿cabe afirmar con rotundidad que únicamente lo que es justo es bello y lo que es

\footnotetext{
${ }^{10}$ DE QUINCEY, T., Del asesinato considerado como una de las Bellas Artes, Madrid 1995.

${ }^{11}$ ROSENKRANZ, K., Estética de lo feo, Madrid 1992.
} 
injusto es feo? Además, para empezar, ¿quien define en nuestra sociedad lo que es bello o feo, o lo que es bueno o malo, o lo que es justo o injusto?

Si aceptamos que lo que es bello, bueno y justo depende de cada uno de nosotros no podríamos objetar nada al que asesina a otra persona o atraca un banco porque el que lo ha hecho dirá que es algo bueno y, probablemente, hasta lo justificará diciendo que es justo. En este sentido, ¿podríamos decir que un dictador es un tirano? Para nosotros su forma de gobernar nos parece injusta y cruel, pero para él esa forma de gobierno será la más justa entre todas las formas posibles.

Este planteamiento nos lleva a pensar que todo sería bello, bueno y justo para unas personas e injusto y horrible para otras. Luego, sobre lo justo y lo bello no cabe ningún saber racional porque se lo dejamos a la opinión y a la emoción de cada uno. ¿Significa esto que no cabe una ciencia capaz de demostrar que lo que es justo es bello y lo que es injusto es feo?, ¿es lícito afirmar que no se puede hablar de una estética de lo injusto?

Si podemos describir los aspectos bellos de lo justo, toda estética que se precie debería tratar de alguna manera, al menos, la negatividad de lo justo e, incluso, valorar si en lo injusto hay algún aspecto destacable desde la perspectiva estética. En todo caso, estaremos de acuerdo en que un estudio sobre la estética de lo justo que no abordara la estética de lo injusto quedaría incompleto.

Es fácil entender, por lo tanto, que lo injusto, como concepto abstracto, sólo puede ser comprendido en referencia a otra categoría y ésta es la de lo justo, pues lo injusto es tal en cuanto que lo justo, que constituye su aspecto positivo, también lo es. Si lo justo no lo fuera, lo injusto no sería nada, pues lo injusto, solo existe en cuanto negación de lo justo. Por consiguiente, lo justo es la idea divina y originaria y lo injusto es su negación y por esto tiene una naturaleza secundaria: se produce a partir de lo justo, no como si lo justo pudiera ser injusto al mismo tiempo, sino en la medida en que se trasforma en su opuesto.

Hasta aquí podemos clasificar las categorías que definen lo justo y lo injusto y establecer el siguiente paralelismo: lo justo es lo positivo y lo injusto es lo negativo; lo justo es la condición necesaria de las cosas, lo injusto es la condición posible; lo justo está en relación directa con la belleza, lo injusto con la fealdad; lo justo es la seguridad, la serenidad, lo injusto es la amenaza, el peligro; lo justo es el bien, lo injusto es el mal; lo justo es lo absoluto, lo injusto lo relativo; lo justo es lo seguro, lo injusto es lo inestable. ¿Puede entonces lo injusto ser valorado estéticamente? 
Esta distinción, que resulta a todas luces evidente, es precisamente la que justifica que lo injusto, como autodestrucción de lo justo, no pueda ser valorado estéticamente. E, incluso, no pueda superar a aquel en la medida en que lo injusto, que sólo existe como lo justo negativo o como el alter de éste, pueda retornar a la unidad con aquel. Diríamos que, en este proceso, lo justo es la fuerza que somete a su dominio la rebelión de lo injusto. Por tanto, la única posibilidad de valorar de manera estética lo injusto es en la medida en que se libera de su negatividad, de su naturaleza, y vuelve a lo justo, retorna a su origen primario, al concepto principal del que ha nacido.

A excepción de las famosas Cartas sobre la educación estética del hombre ${ }^{12}$, la obra estética de Friedrich Schiller quedó eclipsada por su producción dramática y poética y es una verdadera lástima porque en aquel trabajo se recogían cuatro ensayos estéticos del poeta alemán muy adecuados para el examen de la estética judicial que nos proponemos. Concretamente, en el segundo de ellos, titulado Reflexiones sobre el uso de lo vulgar y lo indigno en el arte, Schiller consideraba que lo indigno puede ir asociado a lo temible, y ponía el ejemplo del robo y el asesinato. Un robo es algo indigno, y no puede aspirar a ser representado en ninguna obra de arte seria, pero un asesinato, que moralmente es más reprobable, puede tener fuerza estética porque su indignidad queda eclipsada por lo terrible del acto. Schiller explicaba que un motivo frecuente de goce estético es la fuerza: mientras que el robo es un acto de indignidad rastrera y cobarde; el asesinato muestra una fuerza que nos subyuga con su temor.

Con estos ejemplos, Schiller diferenciaba lo patético, lo vulgar y lo indigno y situaba lo indigno en nivel más inferior que lo vulgar porque, a su juicio, la indignidad es la búsqueda del propio provecho a despecho de los deberes civiles mediante medios despreciables para satisfacer la propia ambición, pero consideraba que, a pesar de estar a un nivel inferior a lo vulgar, lo indigno tiene cabida en el arte porque se separa de la mediocridad de lo vulgar, que no tiene ninguna cabida $\mathrm{y}$, por esto mismo, consideraba que cuando el crimen produce tal horror en el público que su indignidad queda en un segundo plano es factible su representación estética porque se manifiesta un hecho que agita el ánimo con sentimientos que sobrepasan cualesquiera consideraciones éticas.

Hasta aquí, por tanto, sería imposible sostener una estética de lo injusto porque de éste no podemos extraer algo más allá de la propia belleza, salvo la morbosidad y el desprecio. Este fue el pensamiento clásico. Decía Platón que la potencia del bien se ha refugiado en la naturaleza de la belleza ${ }^{13}$. Es

\footnotetext{
${ }^{12}$ Puede leerse en: http://bdigital.uncu.edu.ar/objetos_digitales/7709/schiller-con-tapas.pdf.

${ }^{13}$ PLATON, Filebo o del placer, 65. Vid.: http://www.filosofia.org/cla/pla/azc03019.htm.
} 
decir, lo que es bueno, necesariamente tiene que ser bello. O de otra manera, la belleza sólo puede existir cuando en su naturaleza se refugia la potencia del bien. El hombre es responsable de la dimensión moral del mundo y de la vida. Cuando en su obrar el hombre no se deja guiar por el bien, sino que se dirige al mal, a la injusticia, a la barbarie, su proceder lo aparta de lo moral y de lo justo, pero también de la belleza porque ésta sólo se alberga en la potencia del bien.

Por tanto, bien y belleza van indisolublemente unidas. Ahora bien, ¿se puede desnudar de moralidad un asesinato o cualquier otra tragedia humana que sea injusta y cruel y aprehender únicamente su efecto estético? ¿Es posible disfrutar de manera estética de una muerte violenta e injusta separando su aspecto moral? ¿Cómo podemos admirar estéticamente algo que condenamos moral y jurídicamente?

Karl Rosenkranz, filósofo hegeliano que escribió un delicioso tratado sobre la estética de lo feo decía que el infierno no es sólo ético y religioso, es también estético ${ }^{14}$, y se refería a aquellos artistas (poetas como Dante, pintores como Orcagna o Rubens y músicos como Spohr) que habían puesto ante nuestra sensibilidad a través del arte espantosas figuras malvadas con las que el mal grita y aúlla el desgarramiento de su espíritu para que las contemplemos y admiremos. Entonces, ¿es posible admirar el infierno?

Resulta innegable que la injusticia genera en el ser humano un sentimiento de repulsa al desaparecer precisamente aquello que es consustancial a la lógica y a la razón, como es el bien, lo moral, lo ético, y convertir el hecho trágico en algo extraño, incomprensible, desagradable, terrible y espantoso. Un terremoto o un animal que nos acecha nos asolan porque no somos capaces de prever las reacciones, de entender lo que sucede, pero las disculpamos, pese a su crueldad, a su gravedad, a su maldad, porque comprendemos que se trata de manifestaciones incontrolables de la naturaleza. Sin embargo, cuando se trata de acciones crueles de los seres humanos, de actos espantosos e inhumanos (el hijo que asesina a su padre o a su madre, o alguno de estos a aquel; el jubilado que degolla a su esposa, el adulto que viola a una muchacha joven menor de edad...), esas conductas tan monstruosas, tan deplorables, tan horrorosas e injustas, las rechazamos moral y jurídicamente, sin que ante ellas quepa disculpa alguna porque no cabe comprensión lógica ni racional de tales hechos. En ellas no hay moralidad, ni justicia que las ampare y, por consiguiente, tampoco hay belleza. La belleza, como decía Platón, es inherente a la bondad, se alberga a resguardo de ésta. Pero, realmente, ¿es esto siempre así?, ¿nunca puede apreciarse

\footnotetext{
${ }^{14}$ ROSENKRANZ, K., Estética de lo feo, Madrid 1992.
} 
belleza en un acto injusto?, ¿es necesaria la bondad y la moralidad del acto injusto para poder apreciar su belleza?

Cuando Sócrates fue condenado a beber la cicuta por corromper a los jóvenes atenienses con sus ideas en contra de la creencia de los dioses ancestrales e introducir nuevas divinidades y exhortar a sus discípulos sobre la inmortalidad del alma, nos dejó con su muerte una lección de moralidad y de belleza, a pesar de la injusticia de su muerte, probablemente la muerte más injusta de la Filosofía, porque se mataba no a la persona, sino a las ideas de su pensamiento. Sin embargo, su muerte fue injusta, pero su conducta, no queriendo escapar a esa injusticia pudiendo huir de ella, fue loable, digna de toda moralidad y, por tanto, de un alto grado de sensibilidad y belleza. De hecho, ha sido llevada al arte en numerosas obras de todo tipo plástico.

Lo mismo ocurre con Jesús de Nazaret. Cuando Pilato lo presenta a la multitud diciendo Ecce homo (este es el hombre o he aqui el hombre) $)^{15}$ para reclamar compasión por el quebrantado y torturado, en quien, precisamente, no ha quedado ningún signo de belleza exterior, nos sitúa frente a la misma belleza en el desfigurado injustamente por amar hasta el extremo ${ }^{16}$, porque:

La belleza de la verdad contiene la ofensa, el dolor e incluso el oscuro misterio de la muerte, y que esto sólo puede ser encontrado cuando se acepta el sufrimiento, no cuando se le ignora ${ }^{17}$.

Estos son ejemplos claros de una injusticia radical, pero de estas muertes, sin embargo, tomamos una lectura moral, espiritual, de fe, de amor. Sócrates, muriendo de manera injusta a causa de su pensamiento, nos dejó no sólo una lección de moralidad, sino un cuadro estético por el que el espectador no pasa desapercibido. Lo mismo ocurre con la crucifixión de Jesús de Nazaret. Su muerte, tan injusta y tan cruel es la entronización en la Gloria, y nos deja, además de una lección de amor a Dios, una fe, una esperanza, y un camino a seguir en la vida ${ }^{18}$. Es una expresión máxima de belleza. Morir por los demás nos conmueve, pero nos afecta a la sensibilidad, nos provoca la emoción, nos

15 Esta es la traducción que la Vulgata latina dio a las palabras pronunciadas por Poncio Pilato cuando presentó a Jesús de Nazaret ante la muchedumbre a la que sometía el destino final del reo según el pasaje del Evangelio de Juan 19,5.

${ }^{16}$ Según el relato evangélico: Antes de la fiesta de la Pascua, sabiendo Jesús que habia llegado la hora de pasar de este mundo al Padre, habiendo amado a los suyos que estaban en el mundo, los amó hasta el extremo, Jn. 13,1-15.

${ }^{17}$ RATZINGER, J., Caminos de Jesucristo, Madrid 2004, p. 16.

18 Véase nuestro trabajo RODRÍGUEZ LLAMOSÍ, J. R., "El evangelio del juicio: una clave de lectura del cuarto evangelio", en Ciudad de Dios. Revista agustiniana, vol. 221, 2 (2008) 291-332. 
enseña, aún cuando en su cuerpo torturado y quebrantado no ha quedado ninguna belleza exterior ${ }^{19}$.

En estos supuestos, el crimen injusto pasa a ser un ejemplo moral de vida porque contiene una enseñanza, un misterio, una referencia para la vida. Son muertes crueles, bárbaras, $\mathrm{y}$, a fin de cuentas, terriblemente desagradables, pero son ejemplos de belleza suprema en los que la muerte, el crimen, pasa a convertirse en expresión estética. Despojados de su crueldad y aprehendida exclusivamente su lado moral, su enseñanza, su testimonio ejemplar, puede apreciarse una estética del crimen.

Hay, sin embargo, un aspecto en estos casos, al margen de su enseñanza moral, que contribuye a su valoración estética y es la relativa a la espectacularización del horror, al que me referiré en el siguiente apartado al analizar la estética del crimen desde su escenificación.

\section{LA CUESTIÓN ESTÉTICA DEL CRIMEN}

Hemos visto antes que el crimen, desde su aspecto moral, no puede ser considerado estéticamente porque aborrece la potencia del bien que es consustancial para poder apreciar la belleza, aunque hay supuestos en los que podemos aprehender su lado moral con la enseñanza que nos transmite y en ese caso podemos hablar de una estética del crimen. Se trata de muertes inocentes, crueles e injustas, pero rodeadas de un halo moral que las dota de una increíble belleza. Me he referido a la muerte de Sócrates mediante la cicuta y a la crucifixión de Jesús de Nazaret. En estos casos, la cuestión estética resplandece porque hay un componente exterior que alimenta la lectura moral y favorece la estética del hecho injusto, la apreciación humana sensible, que a fin de cuentas es eso la estética. Me refiero a su escenificación, a su espectacularización.

El horror, la violencia, el crimen es un tema que el arte ha abordado en numerosas ocasiones y con lenguaje y modalidades diferentes. Sin embargo, las manifestaciones artísticas se mueven en un plano ambiguo: por una parte, denuncian la violencia, ciertamente; pero, por otra parte, también la estetizan, la escenifican, la convierten en espectáculo afectando nuestra sensibilidad.

Esta escenificación o espectacularización de la muerte, de la crueldad humana, del crimen, tiene su propia historia que se remonta al mismo origen del hombre,

\footnotetext{
${ }^{19}$ De hecho, es esta una pregunta que en la Teología ocupó a los Padres de la Iglesia: si en ese momento Cristo era hermoso o no. Y es justamente en el rostro desfigurado, en el cuerpo macilento, donde se manifiesta la belleza del amor más fuerte que el odio, la violencia y la injusticia.
} 
y tiene, además, su propio lenguaje dentro del Arte, capaz de expresar batallas sanguinarias, crueles tragedias, sangrientos sacrificios y hasta horrorosos crímenes de las formas plásticas menos imaginables. Todo ello favorece la estética del horror que procura, precisamente, asociar lo bello con lo atroz, mediando la verdad. Pero vayamos por partes. Es preciso analizar los términos para situar el contexto.

Espectáculo procede del latín spectaculum y, éste a su vez, de spectare, que significa contemplar. Su significado, en lengua española, es diversión pública, cosa que llama la atención produciendo deleite, asombro o dolor, y, por último, acción que produce escándalo. El espectáculo, pues, oscila entre acción y cosa, y entre lo privado y lo público. Tanto el motivo en sí como la acción que lo determina devienen espectáculo en la medida en que trascienden el espacio de lo privado para alojarse en lo público. Desde la literatura a la pintura, pasando por la fotografía y llegando hasta el cine, el espectáculo del crimen tiene una larga historia.

Con el espectáculo nace la estilización o estetización del crimen, que son expresiones para indicar la puesta en escena que se hace del horror y la violencia en las distintas facetas del arte como la literatura, la pintura, la fotografía, el cine; en la cultura, y hasta en los medios de comunicación donde se ofrecen distintos planteamientos: unos morales (enfrentándose o no con sus consecuencias, caracterizando positiva o negativamente a las víctimas o a los agresores, etc.) y comunicativos (la explotación del placer morboso de su contemplación por el sensacionalismo, la banalización de la violencia o su sublimación como un aspecto trágico).

El crimen es la crueldad y donde ésta habita impera el mal. El crimen, el asesinato, la muerte injusta de otro ser humano es la brutalidad, la atrocidad, la ferocidad, la barbarie y la violencia máxima, es la insensibilidad hacia el sufrimiento ajeno, es la deshumanización total y absoluta, la más despreciable bajeza humana. Sin embargo, el crimen no es ajeno a su espectacularización, a su puesta en escena, al teatro de operaciones en el que se ofrecen las imágenes de la tragedia, de la crueldad, del crimen y se desvela el ensañamiento, la ferocidad, el dolor ajeno y, en definitiva, el desequilibrio de esa balanza del bien y el mal por la que se rigen nuestros actos humanos. Fue san Agustín quien planteó con profunda belleza teológica el asunto del libre arbitrio respecto al bien y el mal en su célebre Del libre arbitrio:

Si el hombre en sí es un bien y no puede obrar rectamente sino cuando quiere, síguese que por necesidad ha de gozar de libre arbitrio, sin el cual no se concibe que pueda obrar rectamente. $Y$ no porque el libre arbitrio sea el origen del pecado, por eso se ha de creer que nos lo ha 
dado Dios para pecar. Hay, pues, una razón suficiente de habérnosla dado, y es que sin él no podía el hombre vivir rectamente ${ }^{20}$.

En el tema del mal, las imágenes que lo representan tienen múltiples escenografías. Desde la modernidad a la posmodernidad se despliegan sus representaciones desde la ira a la más fría planificación criminal. El mal crea falsos decorados, deforma las figuras, se reviste de diversos disfraces tanto en su guión como en su puesta en escena. Y la espectacularización del mal radica justamente en mostrar sus infames figuras, sus mordaces disfraces, no solo el rostro de dolor del vencido, sino el placer, el coraje o la valentía de su verdugo.

La estética del horror hace confluir en un mismo espectáculo el mal (lo opuesto al bien) y el horror (lo opuesto a lo bello), categorías que se sintetizan en lo inhumano, en lo injusto, mediante su visualización a la que, por desgracia, estamos demasiado familiarizados. Nuestros oídos, nuestros ojos, nuestros sentimientos, se ven a diario afectados por miles de injusticias que ocurren a nuestro alrededor, en nuestra comunidad, en nuestra sociedad, en el mundo entero, y en las que el hombre es el autor, su más despiadado y cruel protagonista.

La celeridad con que en el mundo se conocen las tragedias nos acerca de una manera inmediata y presente a cualquier escenario del horror, del crimen, de la muerte, de la guerra, de la injusticia, ante la que nos sitúa como espectadores poniendo ante nuestros sentidos toda la crudeza y vulgaridad de los acontecimientos, lo informe y lo deforme de la noticia.

Esta espectacularización del crimen, de la tragedia, del horror, de la muerte, puede servirse como denuncia social que lleva consigo una enseñanza, una lectura, una finalidad o como plato frío para el morbo. Cualquier manifestación artística se mueve en ese plano ambiguo: por una parte, critica y denuncia la violencia, ciertamente, pero, por otra parte, también la estetiza, la escenifica, la convierte en espectáculo.

Esta ambigüedad sucede con demasiada frecuencia en los medios de comunicación, más proclives a la espectacularización de las injusticias y la escenificación del horror que a la denuncia social, a la crítica. Con inusitada frialdad, nos ofrecen en el comedor de nuestra propia casa a la hora de la comida o de la cena los cuerpos de seres humanos descuartizados por guerras, quemados en incendios, mutilados en accidentes horribles o en asesinatos crueles, y nos sitúan ante informaciones que suelen ser recurrentes sobre hechos violentos

\footnotetext{
${ }^{20}$ SAN AGUSTÍN, Del libre arbitrio, II,1-2.
} 
injustos en materia de delitos contra la vida y la libertad sexual. Los crímenes reales suscitan programas especiales, con supuestos expertos y periodistas especializados debatiendo hasta los detalles más escabrosos (y cuanto más escabrosos, mejor) sobre el tema. ¿Qué decir de todo esto? ¿Qué sentimiento se puede generar sino el de estupor? Ni son conductas ejemplares, ni éticas, ni morales, ni justas, sino todo lo contrario, además de desagradables y monstruosas. ¿Dónde queda el plano moral y jurídico de denuncia social de la injusticia?, ¿por qué cede ésta ante la escenificación del horror?, ¿resulta más interesante el espectáculo que la crítica y la denuncia de la injusticia?

Lo más terrible es que nos hemos acostumbrado a que sea así. La sensibilidad de la sociedad occidental moderna recuerda a la Roma Imperial cuyos ciudadanos acudían al circo para ver cómo animales voraces acechaban y descuartizaban a hombres y mujeres mientras ellos, espectadores enfervorizados y coléricos, aplaudían, vociferaban y comían. Panis et circensis, decían. Y, acaso, ¿no somos nosotros, en cierto modo, como los espectadores romanos? ¿No está nuestra sensibilidad tan embotada de sangre que necesita cada vez noticias más crueles, más infames, más repugnantes, más sangrantes para poder ser afectada? ¿Qué necesitamos para poder impresionar aún más a nuestra sensibilidad?

Lo que me cuesta entender en todo esto es el interés mediático por el asunto $\mathrm{y}$, desde luego, los intereses comerciales, lo que resulta no sólo ofensivo para las víctimas y los ajenos, sino incluso enfermizo para quienes lo publicitan. El crimen monstruoso no suele ser tratado con afán de informar, de denunciar, de salvar la moralidad del pueblo, sino de alimentar el morbo y sacudir a esa sensibilidad embotada y decadente. Los detalles escabrosos y la exageración informativa contribuyen a ello. Y cuantos más detalles escabrosos, mejor, vuelvo a repetir. Es la crueldad televisada y plastificada. E incluso, más allá de estos fines, parece que los medios de comunicación quisieran producir una catarsis emocional colectiva mediante la indignación, el llanto o el odio hacia el malvado, del mismo modo que miles de personas se emocionan colectivamente ante los pasos de la Semana Santa que representan hechos dramáticos acontecidos en la vida de Jesús de Nazaret, aunque muchos no sean ni creyentes, ni practicantes, ni devotos, ni nada. Este drama colectivo ha sido asumido por la televisión y los diferentes medios de comunicación y es impuesto a los individuos como una forma de provocar un falso sentimiento de cohesión social y unidad completamente ficticio y superficial que satisface la necesidad humana de no sentirse solo, lo que pone de manifiesto la inmadura afectividad de la sensibilidad del hombre occidental, fácilmente manejable por un entorno social patológico ${ }^{21}$.

${ }^{21}$ Véase nuestro trabajo, RODRÍGUEZ LLAMOSÍ, J. R., "Ética judicial y medios de comunicación”, en Anuario Jurídico y Económico Escurialense, 44 (2011), 209-224. 
El problema es que se ha entrado en un círculo vicioso. Los medios de comunicación muestran a diario el crimen en su forma más plástica porque el crimen en sí mismo, lo injusto, lo prohibido, es interés común, no por su ética, ni por su belleza, sino por la morbosa curiosidad, y en su degustación comulga la sociedad desde su más repugnante interés, aun cuando lo condene moral y jurídicamente. Se trata de una absurda cultura de la estética del crimen que los medios de comunicación se encargan de plastificar y presentar a diario ante nuestros ojos en sus más diversas formas. No son historias contadas desde el punto de vista policial, ni siquiera moral, ni jurídico, ni ejemplar, sino morboso, puramente morboso, gracias a un sistema sociopolítico que, como carece de principios éticos, filosóficos y morales, permite la difusión generalizada del crimen como interés económico. Es así como el crimen se convierte en material consumible por un público que lo prueba y lo degusta como si de algo bueno y bello se tratara.

La espectacularización del horror también se encuentra en cualquiera de sus formas artísticas plásticas como la pintura, la fotografía o la literatura. A diferencia de los medios de comunicación, la estética del crimen ha servido en el arte como denuncia social, como crítica, para poner de relieve la injusticia, la inmoralidad, la falta de belleza de la crueldad. Voy a referirme a algunos ejemplos concretos.

En la pintura, por ejemplo, hay un grabado de Goya que me impresiona mucho, tanto como Los fusilamientos del 3 de mayo, que tan magistralmente realizó el pintor aragonés con ese juego de luces que expresa todo el dramatismo de su denuncia: el pueblo, a la luz, en su resistencia; y el gobierno francés, en la oscuridad, actuando al margen de la ley y la humanidad. Se trata de un aguafuerte de la serie Los desastres de la guerra, titulado Grande hazaña con los muertos. En ella se puede apreciar a tres hombres muertos y desnudos atados a un árbol de distinta forma y en diferente condición. Un paisaje árido y desolado enmarca la dantesca escena en donde cuelgan los cadáveres. Goya ordena la escena utilizando una diagonal, desde el lado inferior izquierdo al superior derecho, colocando dos cabezas en los extremos de la composición. Un primer cuerpo boca abajo, con la cabeza y los hombros en el suelo, cuelga de los pies. Un segundo cuerpo, frontal al espectador y que no deja ver su rostro, pende con los brazos tras la espalda atados al tronco del árbol. Un tercer cuerpo, mutilado de brazos y decapitado, cuelga de una rama atado por las piernas. En este último cuerpo -donde se han encarnizado los verdugos-, las partes amputadas han sido desplegadas en otras ramas del árbol, exponiendo el cuerpo en su totalidad pero desmembrado. 
Los cadáveres no fueron enterrados y están ahí con un propósito: ser encontrados. Que sus familiares y comunidades los contemplen con horror. Hay una clara intencionalidad de amedrentamiento en estos asesinatos, que van más allá de los sujetos particulares sacrificados en la escena, dispuesta de tal forma que sólo busca infundir terror. Mientras más horror provoque a los que observen este espectáculo, mayor utilidad tendrá el procedimiento efectuado para el fin perseguido.

Goya representa, por tanto, el terror en sí mismo, despojado de cualquier otro atavío que no sea la propia inhumanidad de lo ahí ocurrido. A los tres cadáveres allí colgados se les han amputado los genitales. Los hombres no solo han sido asesinados y mutilados, sino que también les ha sido arrancada su hombría, desplazando con ello el desmembramiento desde la cabeza (pensar) y los brazos (hacer u obrar), hasta los genitales (procrear). A los cadáveres espectacularizados en la imagen, desmembrados, la comunidad podrá restituirlos a la hora del rito funerario, pero no podrá restituir algo muy importante arrebatado por el asesino: el miembro genital de la simiente con el que se perpetúa la comunidad. Con esta usurpación, el crimen se ha perpetrado en las víctimas, ya muertas, pero también en los vivos, a quienes dirige un mensaje de muerte, más que a los propios muertos, quienes ya no pueden pensar, ni obrar, ni procrear.

La obra de Goya es una clara denuncia de la injusticia, de lo aborrecible y despreciable del crimen. El mensaje dibujado con aguafuerte previene a la comunidad, a la sociedad, y al mismo espectador. Es un aviso para navegantes. Quienes han sido capaces de arrancar la vida, en todos los sentidos, la inteligencia, la razón, la capacidad de hacer y obrar, y hasta de procrear para reproducir la comunidad son capaces de hacerlo con cualquiera de vosotros, espectadores que contempláis esta gran hazaña.

También la fotografía es un escenario para el crimen y la espectacularización del horror. De la mano de la técnica, la fotografía incorpora más verdad sobre la realidad, ciertamente, en cuanto al detalle registrado, que es testimonio o prueba fidedigna de lo acaecido. La fotografía inmortaliza el instante, pero también su crueldad, su horror. Dice Jean Baudrillard en su obra La transparencia del mal. Ensayo sobre los fenómenos extremos (1991) que la imagen fotográfica es dramática, por su silencio, por su inmovilidad, de ahí justamente su elocuencia, por lo que muestra y calla, por lo que oculta y transparenta ${ }^{22}$.

He seleccionado para este ensayo una fotografía cuya elocuencia sobresalta y hace gritar a los ojos del espectador. Se trata de la histórica fotografía tomada en

${ }^{22}$ BAUDRILLARD, J., La transparencia del mal. Ensayo sobre los fenómenos extremos, Barcelona 1991, p. 165. 
Vínnytsia, una ciudad de Ucrania que durante la década de 1930 y principios de la de 1940, fue espacio de crueles masacres, primero durante las purgas de Stalin y luego durante el Holocausto y la ocupación nazi. Lleva por título El último judio de Vínnytsia, y está datada en 1941, aunque es de autor desconocido. En ella, un soldado nazi está a punto de disparar en la nuca a un hombre que mira al objetivo, que nos mira a nosotros, en definitiva, sentado al borde de una fosa llena de cadáveres. Esta es su excepcionalidad, su denuncia. Ese hombre es el último judío de los 28.000 judíos ya muertos que vivían en la ciudad donde el ejército del tercer Reich llevó a la práctica la aniquilación total.

La fotografía muestra todo el dramatismo de la escena que reproduce. La imagen se divide en dos partes, la de arriba, en donde están los soldados alemanes, espectadores de lo que está ocurriendo, y la de abajo, en donde yacen cadáveres desparramados en una fosa común. La escena está tensionada trágicamente por una diagonal que dibuja el brazo del verdugo, joven miembro del Einsatzgruppe D, que usa gafas y apunta su pistola directamente a la nuca de su víctima. La parte de arriba y la parte de abajo se unen en este criminal gesto, donde los espectadores -diversas ramas de la Wehrmacht, del Heer, de las SS y del servicio de trabajo nazi- atestiguan atentos la macabra escena. Y mientras, el hombre, ese judío aterrado, asustado, está sentado en cuclillas al borde de una fosa llena de cadáveres donde su cuerpo, una vez sea despojado de la vida por la bala, va a ser llevado. No hay misericordia alguna por lo que le va a ocurrir a aquel hombre. La frialdad en los rostros de los que atestiguan el crimen está en completa consonancia con la del verdugo que apunta con su pistola, así como con la resignación en el rostro de la víctima que mira, que nos mira. Sus ojos, su mirada nos pide a nosotros, que estamos delante de él, esa misericordia que no existe tras él y suscita nuestra angustia ante la crueldad del soldado y nuestro deseo de irrumpir en la escena y arrebatarle el arma para frustrar tan macabro crimen y acabar de una vez por todas con tan atroz sufrimiento del protagonista. La fotografía da cuenta de una instancia pública donde acontece un asesinato. Lo privado y lo público, otra vez, como decía anteriormente, se solapan perversamente, ocultando-revelando la espectacularización del crimen.

La literatura tampoco es ajena a la estética del horror ${ }^{23}$. Decía Edmund Burke en su Indagación filosófica sobre el origen de nuestras ideas acerca

23 Aunque resulta paradójico, y hasta curioso, que la tragedia griega, precisamente tan infausta, omite la representación verbal de la violencia en escena: los asesinatos, las torturas o las violaciones siempre son obscenas y suceden fuera de la escena, ocultas a la vista del espectador, a quien únicamente se le narran verbalmente en los textos declamados por los actores en sus monólogos o diálogos, o por el coro. En La Orestiada, la famosa tragedia de Esquilo, por ejemplo, que es un ciclo completo de sangrientos homicidios y venganzas, Clitemnestra 
de lo sublime y lo bello (1757) que lo sublime es generado por una idea de sufrimiento y peligro que amenaza la existencia del ser humano ${ }^{24}$. Esta idea es la que, en la literatura, ofrece al canon genérico del horror una base teórica de su estética y una configuración psicológica y narrativa de sus protagonistas que será desarrollada por los autores de la literatura gótica inglesa como se aprecia en novelas como Los misterios de Udolfo (1794) de Ann Radcliffe ${ }^{25}$ y El monje (1796) de Matthew G. Lewis ${ }^{26}$. Más reciente y mucho más destacada es toda la obra de Robert Bloch, especialmente su Psicosis ${ }^{27}$, el Ensayo de un crimen (1943-1944), de Rodolfo Usigli ${ }^{28}$, El asesino dentro de mi (1952) de Jim Thompson ${ }^{29}$ y El talentoso Mr. Ripley (1955) de Patricia Highsmith ${ }^{30}$, entre otras $^{31}$.

mata de una puñalada a Agamenón; Orestes asesina a Clitemnestra..., pero todo ocurre tras los bastidores. En Edipo Rey, una historia de parricidio, incesto, suicidio y ceguera por arrancamiento de los ojos..., nada aparece en el escenario. En la violencia orgiástica de Las Bacantes, de Eurípides, tampoco ocurre nada ante el público.

${ }^{24}$ BURKE, E., Indagación filosófica sobre el origen de nuestras ideas acerca de lo sublime y de lo bello, Madrid 1997, Parte primera, Sección VII: De lo sublime.

${ }^{25}$ Se trata de una novela romántica gótica que se desarrolla en el siglo XVI, y se ubica en el sur de Francia y norte de Italia, sobre las aventuras de la joven Emily Aubert, una joven francesa que ha quedado huérfana después de la muerte de su padre y es encerrada en el castillo Udolfo por Signor Montoni, un malvado ladrón italiano que se ha casado con su tía Madame Cheron, y allí sufre terrores sobrenaturales y las maquinaciones del ladrón malvado Montoni.

${ }^{26}$ Publicada por primera vez en 1796 por su autor, que la escribió antes de cumplir los veinte años y que tardó solo diez semanas en escribirla, sigue siendo hoy una de las primeras novelas góticas más escabrosas y transgresoras cuyo protagonista, un sacerdote español, es presentado como villano, destacando pactos demoníacos, violaciones, incesto, el tema del judío errante, castillos en ruinas y la Inquisición española.

${ }^{27}$ Robert Bloch (1917-1994) fue un novelista y guionista estadounidense, discípulo de H. P. Lovecraft. Su obra se inscribe dentro del género negro, del terror y de la ciencia ficción. Recibió los premios Hugo, Bram Stoker y el premio Mundial de Fantasía. Su obra más universalmente conocida, sin embargo, es Psicosis, llevada al cine en la película del mismo nombre por Alfred Hitchcock en 1960, siendo un clásico del cine.

${ }^{28} \mathrm{Su}$ personaje principal, Roberto de la Cruz se plantea la idea de ser el protagonista de un crimen gratuito y perfecto, pero este sueño no se llega a realizar debido a la falta de reconocimiento social y al fracaso en el asesinato de sus presuntas víctimas. Roberto de la Cruz se toma el crimen como un arte, ya que planea metódicamente cada uno de sus crímenes, apasionado con el tema, como un impulso de predilección sobre su vida, más que un acto por diversión o por venganza u odio, tomando el crimen como su destino en la vida, con un placer extraño de ser asesino.

${ }^{29}$ El mundo narrativo de Jim Thompson es nihilista y está poblado de perdedores, aprovechados, sociópatas y psicópatas. Considerado un maestro en el diseño de los personajes, especialmente los psicópatas, presenta una cosmovisión sombría y cruel de la existencia humana. Su arte novelístico lo resumió en una afortunada frase: Hay 32 maneras de escribir una historia y yo las he usado todas, pero solo hay una trama: las cosas no son lo que parecen. En la novela El asesino dentro de mi, narra el desdoblamiento de personalidad que sufre el sheriff adjunto, Lou Ford, de Central City, una localidad petrolera al oeste de Texas, donde la vida era muy tranquila, hasta que empieza a experimentar recidivas de la enfermedad que le hizo 
También se produce mayor espectacularización del crimen en las novelas de asesinos en serie como Jack el Destripador, quien asesinó brutalmente a cinco mujeres, y la policía nunca lo atrapó, lo que llevó a una mitificación del asesino que aumentó con el paso de los años, por lo que se convirtió en el protagonista de cientos de trabajos históricos y de ficción en los que se produce una experiencia estética a partir de los actos de posesión y aniquilación de cuerpos humanos por parte del protagonista cuyo objetivo es la perfección del asesinato ritual por parte del criminal y la generación de miedo en la sociedad. Para ello confluyen dos lecturas: la del investigador, a nivel intratextual, y la del lector/espectador, a nivel extratextual. Los dos juzgan, desde la perspectiva estética, el crimen.

Hay en la literatura otros asesinos no seriales pero de una carga psicológica capaz de conmover la sensibilidad del lector. Son asesinos detestables y a la vez inolvidables que llaman mi atención por su morbosidad y al mismo tiempo por la defensa de su crimen bajo razonamientos que pretenden hacer lógicos sin serlo. Los móviles son distintos en cada uno: motivos pasionales,

cometer un crimen en su juventud. Desde aquel entonces, el objetivo de Lou se convierte en un rio de sangre, que comienza con las muertes de Joyce Lakeland, una mujer de dudosa moral, y Elmer Conway, hijo de un magnate, además del aparente suicidio del reo Jonien Papas.

${ }^{30}$ Patricia Highsmith (1921-1995) ha sido una de las escasas autoras más adaptadas al cine. Sus historias de crímenes crean una mirada sobre seres humanos donde la ambigüedad moral y ética está a la orden del día y siempre al servicio de los propósitos de sus personajes inquietantes, turbios o perversos. Escribió una veintena de novelas, muchos relatos y algún ensayo. Su debut oficial fue en 1950 con Extraños en un tren con el que alcanzó el éxito casi inmediato. Una prueba fue que Alfred Hitchcock adaptó la novela al cine. Cinco años después vendría su personaje más famoso: Tom Ripley, que nacería en su novela El talento de mister Ripley (1955), en la que ahonda en la psicología del personaje y la facilidad con que el ser humano cree convertir el mal en bien en beneficio propio.

${ }^{31}$ Para los amantes del crimen en la literatura, la editorial Valdemar publicó en el año 2011 un exquisito libro titulado Tras la sombra del asesino. Narra la investigación exhaustiva de un fiscal que ha encontrado a una serie de escritores culpables de haber perpetrado las mejores historias policiacas publicadas en Valdemar, y de dar vida a algunos de los detectives más carismáticos de la literatura de misterio (como Auguste Dupin, Sherlock Holmes, el padre Brown, J.G. Reeder o Jules de Grandin). Entre los imputados se encuentran los instigadores del crimen (Defoe, Radcliffe, De Quincey o Le Fanu) planeado por el cabecilla y cerebro de la trama, el señor Edgar Allan Poe, cuyas fechorías han sido llevadas hasta sus últimas consecuencias por diferentes cómplices (Willkie Collins, Conan Doyle, Chesterton, Edgar Wallace, Dickson Carr...). Son muchos los letrados que han defendido casos similares (Dickens, Melville, Stevenson, Conrad o Kipling), y numerosos los condenados con anterioridad por crímenes tan terroríficos (Bram Stoker, Guy de Maupassant, Robert Bloch...), así como los timadores y falsos culpables implicados en este peligroso juego (Mark Twain, Voltaire o Jardiel Poncela). A todos ellos se les acusa de alevosía en la comisión del delito, movidos, no obstante, por el encomiable propósito de obtener el valioso botín que el lector tiene ahora en sus manos. El tribunal ha expuesto los hechos en este voluminoso sumario. Ahora les toca a ustedes decidir, distinguido e implacable jurado, y emitir su veredicto. 
ideología y, en el último, por cuestión puramente estética. Si bien la lista podría ampliarse mucho más.

El primero es Posdnicheff, un asesino pasional, celoso, depravado, víctima de su propia infancia, de sus propios ideales acerca de las mujeres y del matrimonio, protagonista de la novela La Sonata de Kreutzer, del escritor ruso León Tolstoi ${ }^{32}$. De él nos da repulsa su moral, sus ideas, pero consigue en el lector algo muy importante: la repulsa de su conducta y la defensa de los ideales que tenemos todos los ciudadanos civilizados.

El segundo es el oficial de una colonia penitencia que, víctima de su propia ideología, de su propia defensa de la ejecución pública bajo una máquina repulsiva que graba la pena en la espalda de la víctima, terminará por probar la máquina como víctima de su propia ideologización. Y de éste se ocupa Frank Kafka en su maravillosa novela En la colonia penitenciaria ${ }^{33}$. De este asesino nos indigna su cuidado de la máquina asesina, pero consigue en el lector el rechazo de tales mecanismos de tortura.

Y el último es un personaje anónimo que se autoidentifica como un hombre morbosamente virtuoso, quien ha logrado leer una Conferencia perteneciente a una Sociedad de Conocedores o Expertos en el Asesinato que admiran la belleza del crimen. A ellos se refiere Del asesinato considerado como una de las Bellas Artes, la obra de Thomas de Quincey, cuya lectura levanta sobre el lector la incógnita sobre la belleza del crimen que es, precisamente, la que ha dado origen a este ensayo.

Los tres protagonistas son asesinos, son repugnantes, devastadores, crueles, dementes, pero los tres, desde la demencia, desde la locura, desde el crimen, enseñan que el paradigma del que son precisamente víctimas es el ideal verdadero del hombre. De la lectura de estas obras se obtiene una conclusión: no es el

${ }^{32}$ La novela toma su título de la composición homónima para violín y piano de Ludwig van Beethoven dedicada a Rodolphe Kreutzer. Se publicó en 1889 y fue censurada al poco tiempo por las autoridades rusas. Es un alegato sobre el ideal de la abstinencia sexual y un tratado exhaustivo en primera persona acerca del sentimiento de los celos. En ella se entrevén los celos que tuvo Tolstói por el encaprichamiento de su mujer Sofía Behrs con el compositor Serguéi Tanéyev y su música.

${ }^{33}$ En la Colonia Penitenciaria es una novela corta escrita por Franz Kafka en octubre de 1914, revisada en noviembre de 1918, y publicada por primera vez en octubre de 1919. La historia se sitúa en una colonia penitenciaria sin nombre. El narrador de la historia parece reaccionar indiferente hacia eventos a los que uno, por lo general, reaccionaría de manera terrorífica. En ella se describe el último uso de un elaborado instrumento de tortura y ejecución que esculpe la sentencia del condenado en su piel para luego dejarlo morir en el transcurso de las 12 horas siguientes. Puede leerse en: https://www.biblioteca.org.ar/libros/11395.pdf. 
matrimonio, ni la familia, ni el amor los que matan, sino la falta de amor; no es la ideología la que destruye, sino la ideologización de las máquinas; no es la estética del crimen la que lo hace bello, sino precisamente su justicia.

Ciertamente, lo que hace bello el crimen es su justicia. Es lo que justifica una estética de la crueldad. Sólo cuando la justicia restablece el orden, la sanción del mal, cuando se retorna lo ingrato, lo cruel, lo criminal, lo injusto a lo bueno, a lo justo, al resarcimiento del daño, al reconocimiento del dolor, a la reparación de las heridas causadas, sólo entonces es cuando se puede hablar de una estética del crimen. Sabemos, por Platón, que sólo en la potencia del bien se alberga la belleza. Pues bien, cuando el bien se ha quebrantado, solo la justicia puede restablecer ese orden quebrado castigando al culpable, ordenando el resarcimiento de los perjuicios, imponiendo la sanción por quebrantarlo. En ese juzgar, en ese hacer justicia, en ese sancionar el daño y reparar el dolor, sólo en esa acción, cuando la justicia castiga el mal y lo retorna a la potencia del bien, es cuando podemos afirmar que es posible una estética del crimen. 